\title{
Beneficial Bacteria Helpful to Restore Water Bodies
}

\author{
SARFRAZ HASHIM ${ }^{1 *}$, XIE YUEBO ${ }^{1}$ and AMOS T. KABO-BAH ${ }^{2}$ \\ ${ }^{1}$ State Key Laboratory of Hydrology-Water Resources, Hohai University, Nanjing, 210098, China. \\ ${ }^{2}$ Department of Energy and Environment Engineering University of \\ Energy and Natural Resources P. O. Box 214, Sunyani, Ghana. \\ *Corresponding author E-mail: engr_sarfrazhashim @yahoo.com \\ http://dx.doi.org/10.13005/ojc/300361
}

(Received: July 07, 2014; Accepted: August 06, 2014)

\begin{abstract}
Population increases by two people in urban cities. In fact, the majority of urban population is blighted and slums due to unsafe and optimal facilities for the community. Here we need to improve the existing sewage facilities with advance, reliable and affordable technologies. The objective of this paper is to introduce some beneficial bacteria that have to restore the water bodies and also helpful to produce an Eco friendly environment.
\end{abstract}

Key words: Bacteria, Water pollution, Sewege Waste water.

\section{INTRODUCTION}

The global population growth rate is accelerating, especially in the developing countries. Though many measures are being put in by developing nations to curb or minimize this population explosion, it is expected by the years 2025 and 2050 , the developing world would experience population volume more than has ever been recorded in history (Massoud 2009). According to a recent survey, there are more than 30 thousands districts nationwide and they have become the target for most people to have a decent style of living. Unfortunately, the domestic sewage of most districts in these places has not been carefully planned leading to untreated sewage discharged into rivers. Domestic sewage usually mixed by excrement and kitchen wastewater, contains a large number of nitrogen, phosphorus and oil. As a result, it becomes an important source and catalyst for river and lakes eutrophication (Kabobah 2013). This is alarming news for the already pressured social amenities present in developing countries. These countries that are already struggling to fight against hunger and poverty, would they be able to meet the provision of basic and key social needs such as safe and reliable access to water and sanitation. The constitutional assumption being that, rural people leave their original residence because of polluted potable water, waterborne and skin infection diseases, but urban environmental air pollution reached the cities to be more threatened (Vennemo 2009). To provide a remedy to this current situation peculiar in developing world and now in China, the fastest developing country today, the bacterial technology was explored in this study. Bacterial technology is one of the best and advance technology that has been recognized as a convenient way to restore polluted water bodies into natural 
quality forms. It resolved by the traditional artificial methods of a biological pond, which extended the subsequently concept of wetlands. It was pointed out, that the technology has multiple benefits for water quality remediation of rivers in urban communities in China (Xie \& song 2012) and elsewhere. The reasons include, but not excluding simplicity, adaptability, affordability, scalability and Eco-friendliness of the technology (Kabo-bah 2012). Apart from these basic facts about this technology, it has been and can be successfully applied aside polluted rivers to various polluted systems such as wastewater treatment plants and septic tanks (song 2011). As such, this article adopts the method of adding the origin-microorganism (Bacterial Clusterization) directly into domestic septic tank. The logic behind this method is that the domesticated the anaerobic and facultative anaerobic bacteria are cultivated into effective living bacteria group. The method builds on the advantages of biological responses to decay the organic pollutant of septic tank and municipal administration pipe network and wetlands.

Bacterial technology procedure held under three types of material (Bacterial Clusterization, Nature Liquid and Biological filter media). Bacterial Clusterization $(\mathrm{BC})$ is an important material that has a mixture of three types of ingredients (Baneficial Bacteria, Mix Medium and water). To produce BC with the specific amount of above ingredients that explained in Table 1. The mixing ratio represents that its harmless and have no any adverse effects.

Nature Liquid (NL) is the mixture of trace element, multiple enzymes, amino acid, vitamins, humic acid and composition of each effective substance on judgment. Biological Filter Media use on a domestic level as the gap string filter media for septic tanks. The results of the study revealed that the water quality was worse before the treatment of effluents added through various horrific points. After the treatment, the polluted situation in septic tank was restored with bacterial technology. The restoring results of before without and after with treatment programs are shown in Fig 1. Both results indicate that, there was noticeable improvement and asset in the restoration back to a livable environment as can be seen. Water quality parameters also show a remarkable achievement before and after the implement with the bacterial technology as Chemical oxygen demand (COD), Total Phosphorus (TP) and Total Nitrogen (TN) removes up to $88.8 \%, 74.5 \%$ and $67.3 \%$ respectively. The presence of fecal coliform is equal to zero, and there is no surface sludge for each septic tank.

Table 1: Bacterial Clusterization for treatment of Sewage Waste Water

\begin{tabular}{|c|c|c|c|c|}
\hline Ingridients & Ratio & Species Name & Species Amount & Species Ratio \\
\hline \multirow[t]{5}{*}{ Bacteria } & 4 & Bacilli & $20 \mathrm{Kg}$ & $6: 4: 3: 4: 3$ \\
\hline & & Lactic & $13.5 \mathrm{Kg}$ & \\
\hline & & Brown- rot Spindle & $10 \mathrm{Kg}$ & \\
\hline & & Anaerobic & $13.5 \mathrm{Kg}$ & \\
\hline & & Denitrifying & $10 \mathrm{Kg}$ & \\
\hline \multirow[t]{11}{*}{ Mixed Medium } & 3 & Liquori root & $1 \mathrm{~kg}$ & - \\
\hline & & Magnesium sulphate & $50 \mathrm{~g}$ & \\
\hline & & Dipotasium hyd & $50 \mathrm{~g}$ & \\
\hline & & Mannitol & $20 \mathrm{~g}$ & \\
\hline & & Cellouse Liquid & $4 \mathrm{~kg}$ & \\
\hline & & Yeast cream & $3 \mathrm{~kg}$ & \\
\hline & & Glucose & $10 \mathrm{~kg}$ & \\
\hline & & Sucrose & $30 \mathrm{~kg}$ & \\
\hline & & Tartaric acid (Na; K) & $50 \mathrm{~g}$ & \\
\hline & & Folic acid & $3 g$ & \\
\hline & & Amounium Nitrate & $50 \mathrm{~g}$ & \\
\hline Water & 3 & Water & $50 \mathrm{Kg}$ & - \\
\hline
\end{tabular}



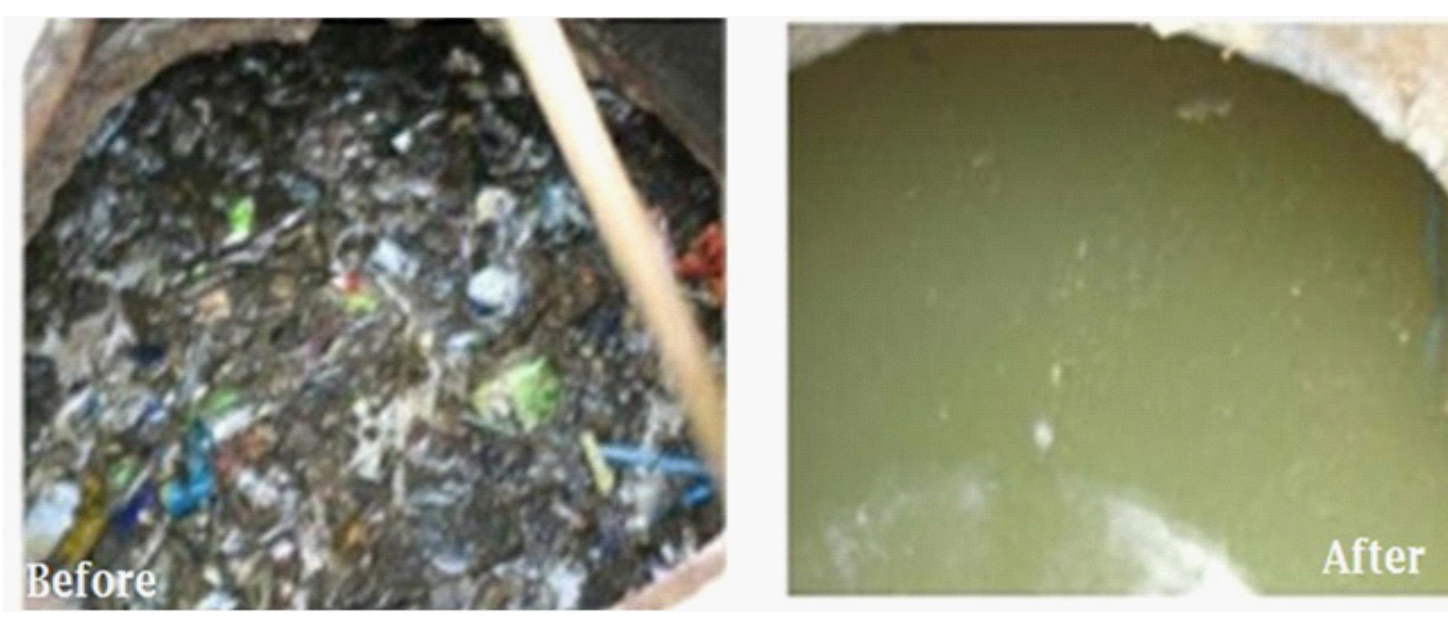

Fig. 1: Contrast diagram of bacterial implimentation before and after treatment

Bacterial technology is one of the advance technologies that has been recognized as a convenient way to restore polluted water bodies into natural quality forms. In order to restore the water bodies, Bacterial technology is safe for public health, sustainable and reliable with no maintenance and farther general costs to minimize the traditional system.

\section{REFERENCES}

1. Massoud, M.A., A. Tarhini, and J.A. Nasr. J. Env. Manag. 2009, 90(1), 652-659.

2. Kabo-bah, A.T., Yuebo, X., James, O., Mark, A \& Guan, y. Orient. J. Chem. 2013, 29(1),121122

3. Vennemo, H., Kristin, A., Lindhjem, H \& Hans, M. S., Rev Environ Econ Policy. 2009, 3(2), 209-230.
4. Yuebo, X., A.T. Kabo-bah, and S. Yajing, J. Appl. Sci. Env. Sanit. 2012, 2(2), 87-93

5. Kabo-bah, A.T., X. Yuebo, and S. Yajing. J. Appl. Sci. Env. Sanit. 2012, 7(4), 231-236

6. Song, Y., X. Yuebo, and F. Peng. Eco-friendly domestic sewage treatment with bacterial technology. 2011: (IEEE Conference) 